DOI: 10.46340/eppd.2021.8.5.13

\author{
Anastasiia Klymenko \\ ORCID ID: https://orcid.org/0000-0002-5831-8025 \\ Odesa Regional Institute of Public Administration \\ of the NAPA under the President of Ukraine
}

\title{
MOTIVATION OF SOCIAL SERVISES' PROVIDERS AS AN INSTRUMENT FOR THE FORMATION OF SOCIAL TRUST IN THE COMMUNITY
}

\author{
Анастасія Клименко \\ Одеський регіональний інститут державного управління НАДУ \\ при Президентові України

\section{МОТИВАЦІЯ НАДАВАЧІВ СОЦАЛЛЬИХ ПОСЛУГ ЯК ІНСТРУМЕНТ ФОРМУВАННЯ СОЦІАЛЬНОЇ ДОВІРИ В ГРОМАДІ}

The article deals with a theoretical analysis of the motivation of employees of local selfgovernment bodies. Among the main components of its formation, have been identified: financial promotion, moral stimulation, creation of conditions for promoting and increasing the prestige of work. On the basis of the analysis of domestic and foreign works, the main factors of motivation of employees who influence the labor activity of social services providers are allocated. The peculiarities of the professional status and official duties of social workers, social work specialists, social managers and social workers of social services providers who work with persons, families who were in difficult living conditions are analyzed. It is also clear that in the process of providing social services between the provider and the recipient of social services there is a communication, which, with its proper use, helps to find mutual understanding and confidence. Important in this case is to receive feedback, assimilation of necessary knowledge, and skills to the recipient of services. For the possession of effective communication techniques, advanced training in the field of provision of social services, employees of social services providers are necessary to implement professional development, acquiring new competencies. During the study, the motivation of social services providers, it has been established that in connection with the implementation of continuous communication with people, in particular with persons, families belonging to unprotected groups of the population, employees are threatened by professional burnout. In order to prevent such a syndrome, a series of preventive measures is proposed.

In order to form social confidence in the community, local self-government bodies, it is proposed to create conditions for psychological, social, career development of employees of social services providers with systematic financial promotion in accordance with the results of work aimed at preventing difficult life circumstances, overcoming or minimize their negative consequences for individuals, families that are in difficult life circumstances.

Keywords: territorial community, local self-government bodies, motivation of local selfgovernment officials, social trust, social services.

Постановка проблеми. В умовах проведення реформи децентралізації соціальних послуг та у зв'язку зі змінами в адміністративно територіальному устрою, надзвичайно актуальним стає формування соціальної довіри у жителів новостворених територіальних громад. Посередником між владою органів місцевого самоврядування та жителями територіальної громади, які узв'язку з різними життєвими обставинами потребують допомоги та захисту $є$ працівники надавачів соціальних послуг. 
Під час реформування, повноваження з надання соціальних послуг, було передано на рівень громад, з метою максимального наближення їх до отримувачів соціальних послуг. Кожна територіальна громада зобов'язана надавати базові соціальні послуги у межах своєї території. Такий перехідний процес не $\epsilon$ простим, керівництво міста, села та селища, зустрічаються 3 труднощами забезпечення отримання усього переліку базових соціальних послуг в громаді, передбачаючи для цього необхідні приміщення, виділення фінансів та забезпечення кадрів. Нестача кваліфікованих спеціалістів для здійснення роботи з найменше захищеними верствами населення, особами, сім'ями, які опинилися в складних життєвих обставинах (далі - СЖО) є однією з найактуальніших проблем управлінців. Так як, згадана категорія населення потребує особливої уваги, необхідним $€$ проведення роботи спрямованої на мотивацію фахівців, які здатні здійснювати надання базових соціальних послуг у громаді.

Аналіз останніх досліджень і публікацій. При дослідженні поставленої проблеми було розглянуто праці сучасних вітчизняних та зарубіжних учених, сфера наукових інтересів яких пов'язана з висунутою проблематикою, мотивацією праці в організаціях, установах, підприємств, зокрема в органах місцевого самоврядування, закладах комунальної власності органів місцевого самоврядування Ф. Герцберга, Ф.Тейлора, Д. Макклелланда, А. Маслоу, В. Бондара, О. Голинської, Н. Гончарука, М. Іжі М. Кравченко, Л. Круп'яка, В. Малиновського, І. Матвєєнко, Л. Рарок, Ю. Палагнюк, Т. Пахомової, Г. Слозанської та інших дослідників.

Зважаючи на наукову цінність праць зазначених авторів, визнавши актуальність зазначеного напрямку дослідження, доцільним $є$ виявити чинники мотивації праці працівників надавачів соціальних послуг та надати рекомендації органам місцевого самоврядування для формування соціальної довіри в громаді.

Метою даної статті $\epsilon$ здійснення теоретичного аналізу та виявлення чинників, що здійснюють вплив на мотивацію праці посадових осіб місцевого самоврядування - надавачів соціальних послуг, як таких, які працюють з особами/сім'ями, які опинилися в складних життєвих обставинах та надання рекомендацій органам місцевого самоврядування щодо формування соціальної довіри в громаді.

Виклад основного матеріалу Мотивація знаходиться в основі будь-яких нововведень, що ведуть до змін у поведінці працівника, підходів до виконання посадових обов'язків, сприйняття інновацій в роботі. До нововведень у сфері надання соціальних послуг, слід віднести сучасні підходи до адміністрування соціального захисту на рівні територіальних громад. На нашу думку, застосування мотивації як інструмента, який впливає на якість виконання соціальної роботи працівниками надавачів соціальних послуг є основою формування соціальної довіри в громаді.

Основними засадами здійснення адміністрування соціального захисту на рівні територіальної громади, зокрема надання соціальних послуг є створення органами місцевого самоврядування системи надавачів соціальних послуг для забезпечення базовими соціальними послугами жителів громади.

До базових соціальних послуг належить: інформування, консультування, соціальна профілактика, соціальна адаптація, представництво інтересів, соціальний супровід, натуральна допомога, догляд вдома, підтримане проживання, фізичний супровід осіб з інвалідністю, переклад жестовою мовою, супровід під час інклюзивного навчання, догляд та виховання дітей в умовах, наближених до сімейних ${ }^{1}$ Таким чином, працівникам надавачів соціальних послуг потрібно мати знання з юридичних, психологічних, соціально-економічних та інших питань. Також надавачам соціальних послуг потрібно мати в штаті спеціалістів, які мають особливі навички, наприклад перекладач жестової мови тощо.

3 метою організації надання базових соціальних послуг, органам місцевого самоврядування, необхідно створити мережу надавачів, які можуть бути віднесені як до державного (комунального) сектору так і до недержавного сектору.

До державних суб'єктів надання соціальних послуг відносяться: центри соціальних служб (ЦСС), центри надання соціальних послуг (ЦНСП), територіальні центри соціального обслуговування (ТЦСО), центри соціально-психологічної допомоги (ЦСПД), центри комплексної реабілітації для осіб з інвалідністю, центри реінтеграції бездомних осіб, центри соціальної адаптації звільнених осіб та інші.

\footnotetext{
1 Закон Украйни Про соиіальні послуги, 2019 (Верховна Рада України). Офіційний сайт Верховної Ради України <https://zakon.rada.gov.ua/laws/show/2671-19\#Техt> (2021, серпень, 08).
} 
До суб'єктів (надавачів) соціальних послуг недержавного сектору належать підприємства, установи, організації, громадські об'єднання, благодійні, релігійні організації, фізичні особи підприємці та фізичні особи, які надають соціальні послуги з догляду відповідно до законодавства без здійснення підприємницької діяльності. Такі суб'єкти (надавачі) можуть бути залучені шляхом соціального замовлення, державно-приватного партнерства, конкурсу соціальних проектів, соціальних програм тощо ${ }^{1}$.

Головне завдання, яке стоїть перед керівництвом органів місцевого самоврядування територіальних громад $€$ створення мережі надавачів соціальних послуг 3 дотриманням державних стандартів надання соціальних послуг та забезпечення кваліфікованими працівниками надавачів соціальних послуг.

До працівників надавачів соціальних послуг комунальних установ органів місцевого самоврядування належать фахівці та професіонали (соціальні працівники, фахівці із соціальної роботи, соціальні менеджери) та соціальні робітники ${ }^{2}$.

3 метою виявлення чинників, які здійснюють вплив на мотивацію праці працівників надавачів соціальних послуг, необхідним є дослідити особливості статусу та обов'язків кожного працівника надавачів соціальних послуг більш детально.

Соціальний працівник є надавачем соціальних послуг, має професійну підготовку, необхідну кваліфікацію у сфері соціальної роботи. В своїй роботі соціальний працівник надає соціальні послуги, формує компетентності самостійного вирішення своїх потреб відповідно до індивідуального плану отримувача соціальних послуг ${ }^{3}$.

Фахівець із соціальної роботи є працівником, який має відповідну освіту та кваліфікацію, здійснює повноваження в оцінюванні потреб у соціальних послугах сімей, дітей та молоді, планує соціальну роботу, визначаючи іiі методи застосування для осіб/сімей, які опинилися в СЖО, надає соціальні послуги та соціальну допомогу, здійснює представництво інтересів отримувача соціальних послугах в установах та організаціях ${ }^{4}$.

Основною різницею між фахівцем із соціальної роботи та соціальним працівником у сфері надання соціальних послуг $є$ категорії їх отримувачів. Якщо фахівець із соціальної роботи надає соціальні послуги сім'ям та дітям, то соціальний працівник надає соціальні послуги іншим групам клієнтів, які відносяться до незахищених верств населення (особи похилого віку, особи з інвалідністю, тяжко хворі).

У новому Законі України «Про соціальні послуги», вперше з'явився працівник сфери надання соціальних послуг - соиіальний менеджер, який має в громаді такі повноваження: планування, організація, моніторинг здійснення соціальної роботи та надання соціальних послуг в громаді, залучення ресурсів для здійснення соціальної роботи та надання соціальних послуг, звітування місцевим органам влади, подання до місцевих органів влади пропозиції щодо удосконалення місцевих програм, що передбачають здійснення соціальної роботи та надання соціальних послуг, проведення інформаційно-роз'яснювальної роботи щодо соціальної роботи та надання соціальних послуг, оцінювання потреб у соціальних послугах сімей, дітей та молоді 5

Різниця між фахівцем із соціальної роботи та соціальним менеджером полягає в тому, що фахівець із соціальної роботи планує соціальну роботу, визначаючи методи соціальної роботи для осіб/сімей, які є отримувачами послуг, на відмінну від соціального менеджера, який планує соціальну роботу та визначає методи ії надання в громаді у цілому.

Не менш важливим працівником, який має безпосереднє відношення до надання соціальних послуг є соиіальний робітник. Такий працівник не здійснює соціальну роботу, проте залучається

\footnotetext{
${ }^{1}$ Децентралізація (2019). Посібник із визначення потреб населення об'єднаної територіальної громади у соціальних послугах. Практичні рекомендації. Київ.<https://decentralization.gov.ua/uploads/library/file/496/> (2021, серпень, 20).

2 Закон України Про соиіальні послуги, 2019 (Верховна Рада України). Офіиійний сайт Верховної Ради Украӥни $<$ https://zakon.rada.gov.ua/laws/show/2671-19\#Text> (2021, серпень, 08).

${ }_{3}^{3}$ Безпалько, О. В., Звєрєва, І. Д., Кияниця, 3. П, Кузьмінський, В. О. (2007). Інтегровані соиіальні служби: теорія, практика, інновації. Київ: Фенікс. (2021, серпень, 08).

${ }^{4}$ Кияниця, 3. П., Петрочко, Ж. В. (2017). Сучасні орієнтири та ключові технології. Соціальна робота

з вразливими сім'ями та дітьми. Київ: Обнова Компані, 1. (2021, серпень,08)

5 Закон України Про соиіальні послуги, 2019 (Верховна Рада України). Офіиійний сайт Верховної Ради Украӥни $<$ https://zakon.rada.gov.ua/laws/show/2671-19\#Text> (2021, серпень, 08).
} 
до надання соціальних послуг. До соціального робітника не має вимог щодо освіти та відповідної кваліфікації, але є обов'язковим проходження відповідної підготовки для надання певної послуги. Таким чином, соціальні робітники можуть залучатися до надання послуги з фізичного супроводу осіб з інвалідністю, послуги супроводу під час інклюзивного навчання та послуги догляду, наприклад доставка продуктів, медикаментів, приготування їжі, допомога під час здійснення заходів особистої гігієни тощо ${ }^{1}$

Слід зазначити, що для надання соціальних послуг можуть залучатися як і вищезгадані працівники та і інші професіонали (перекладачі жестовою мовою, психологи, юристи).

Отже, дослідивши особливості професійного статусу та посадових обов'язків кожного працівника надавачів соціальних послуг, можливо зробити висновок, що трудова діяльність соціальних працівників, фахівців із соціальної роботи, соціальних менеджерів та соціальних робітників несе велику цінність суспільство, підтримує соціально незахищених верств населення, здійснює соціальну роботу та надає соціальні послуги.

У процесі надання соціальних послуг між надавачем та отримувачем соціальних послуг виникає комунікація, що передбачає процес обміну думками, ідеями, фактами 3 важливими для досягнення мети подолання або мінімізації складних життєвих обставин отримувача послуги. Основною метою комунікації є досягнення взаєморозуміння та отримання довіри. Щоб комунікація була результативною необхідним $є$ визначити та застосувати ті методи, які впливають на досягнення кінцевого результату. Важливим у даному випадку $є$ отримання зворотного зв'язку, засвоєння необхідних компетенцій отримувача послуги ${ }^{2}$.

Таким чином, працівники надавачів соціальних послуг під час здійснення своєї трудової діяльності знаходиться у постійній комунікації з отримувачами соціальних послуг. Така робота вимагає постійного особистісного спілкування, вміння контактувати з людьми, переконувати i пристосовуватися, обслуговувати, виховувати, допомагати, а також ефективно вирішувати конфлікти, спираючись на інтуїцію і емоційний контакт, що може призводити до емоційного вигорання. Під емоційним вигоранням на службі, слід розуміти фізичне, емоційне або мотиваційне виснаження - тобто результат надмірного і тривалого навантаження та стресів у професійній діяльності ${ }^{3}$.

Таблиця 1

Сутність чинників вмотивованості працівників надавачів соціальних послуг

\begin{tabular}{|l|l|l|}
\hline \multicolumn{1}{|c|}{ № } & \multicolumn{1}{|c|}{ Назва чинника } & \multicolumn{1}{c|}{ Зміст чинника } \\
\hline 1. & психологічний & $\begin{array}{l}\text { внутрішній стан працівника, його місце у суспільстві, } \\
\text { соціальний та сімейний статус); }\end{array}$ \\
\hline 2. & соціальний & $\begin{array}{l}\text { місце працівника в колективі серед працівників надавачів } \\
\text { соціальних послуг, приналежність до громадського } \\
\text { об’єднання / організації / фонду, участь в місцевих обговореннях } \\
\text { соціальної сфери, колективих зборах; }\end{array}$ \\
\hline 3. & кар’єрний & можливість просування по службі, професійний розвиток; \\
\hline 4. & освітній & $\begin{array}{l}\text { підвищення кваліфікації, участь у конференціях, опанування } \\
\text { нових освітніх програм }\end{array}$ \\
\hline 5. & матеріальний & грошові заохочення, премії, соціальні пільги, страхування. \\
\hline
\end{tabular}

\footnotetext{
${ }^{1}$ Семигіна, Т. (2020). Сучасна соціальна робота. Київ: Академія праці, соціальних відносин і туризму <https://www.researchgate.net/profile/Tetyana-Semigina/publication/342003632_Sucasna_socialna_robota/links/ 5eddf6ae299bf1d20bd86768/Sucasna-socialna-robota.pdf> (2021, серпень,08).

${ }^{2}$ Коберник, І., Краснова, К. (2019). Ефективні комунікації для освітніх управлінців. Нова Украӥнська школа <https://nus.org.ua/wp-content/uploads/2019/12/efektyvni-komunikacii-posibnyk-final-preview-20-12.pdf> (2021, серпень, 16).

${ }^{3}$ Там само.
} 
3 метою запобігання виникнення професійного вигорання, яке здійснює вплив на мотивацію праці працівників надавачів соціальних послуг, як таких, які працюють 3 незахищеними верствами населення, проаналізувавши зарубіжні та вітчизняні праці науковців, виділимо такі чинники підвищення рівня вмотивованості (табл.1).

Виділивши чинники, які здійснюють вплив на мотивацію праці працівників надавачів соціальних послуг, необхідним є здійснення належного управління та професійного розвитку кожного окремо взятого працівника установи. На нашу думку, приділення уваги мотивації працівників надавачів соціальних послуг, $є$ запорукою розвитку системи надання соціальних послуг в громаді.

На думку, В. Бондара, мотивація працівників представників органів місцевого самоврядування - це сукупність внутрішніх та зовнішніх мотиваторів, які реалізуються через систему позитивних та негативних способів впливу на мотиваційне поле працівників з метою досягнення соціально значимих результатів в їх діяльності. Основними напрямами підвищення мотивації посадових осіб місцевого самоврядування науковець виділяє: матеріальне заохочення, яке повинно залежати від результатів роботи, моральне стимулювання, створення сприятливих умов для кар'єрного просування по службі, підвищення престижу роботи та діяльність керівників спрямована на мотивування підлеглих ${ }^{1}$.

Таким чином, ми погоджуємося з ефективністю застосування таких напрямів підвищення мотивації посадових осіб місцевого самоврядування та вважаємо за доцільне застосовувати їх і для працівників надавачів соціальних послуг.

Колективів авторів М. Іжа, О. Голинська, І. Матвєєнко досліджуючи особливості підготовки кадрів місцевого самоврядування та наголошуючи на зростанні ролі кадрово-організаційної та інституційної спроможності місцевого самоврядування в економічному і соціальному розвитку держави та регіонів, акцентують увагу на професійній освіті, яка спроможна створити нову парадигму кількісного та якісного відтворення кадрового потенціалу держави ${ }^{2}$.

У контексті даного дослідження ми погоджуємося з науковцями, та наголошуємо на необхідності застосування освітнього чинника, в якості професійної освіти, що слугує мотивацією працівників надавачів соціальних послуг до професійного розвитку, самовдосконалення, опанування нових освітніх програм. Також, здобуття професійної освіти стимулює розвиток надання соціальних послуг, шляхом отримання працівниками надавачів соціальних послуг актуальних знань, умінь та навичок.

Дослідниця Ю. Палагнюк, розглядаючи методи мотивування персоналу органів місцевого самоврядування відзначає необхідність застосування як матеріальних так і нематеріальних стимулів. До нематеріальних стимулів на думку авторки, слід застосовувати «соціальні контакти» та «стійкі взаємовідносини», оскільки працівники бажають отримувати задоволення й позитивні емоції від багатьох контактів з іншими людьми, що є особливо важливим під час роботи в органах місцевого самоврядування. Тому керівникові слід формувати такий моральний клімат у колективі, що буде заохочувати взаємини. Тоді працівники будуть задоволені працювати в умовах довіри, сприятливих робочих і особистих взаємин, властивих ефективній команді ${ }^{3}$.

Отже, ми погоджуємося, що варто взяти до уваги застосування «соціальних контактів» та «стійких взаємовідносин», з колегами професіоналами у неформальній обстановці, що допоможе запобігти професійному вигоранню під час надання соціальних послуг працюючих з незахищеними верствами населення, які опинилися в СЖО. На нашу думку, будь-яка соціальна активність допомагає запобігти професійному вигоранню методом перемикання уваги. Участь у психологічних тренінгах, семінарах розвантажує психіку працівника. Також до професійної підтримки працівника

\footnotetext{
${ }^{1}$ Бондар, В. Д. (2012) Мотивація діяльності органів місцевого самоврядування: поняття та основні теоретичні положення. Державне управління: удосконалення та розвиток, 5

<http://www.dy.nayka.com.ua/?op=1\&z=435http://el-zbirn-du.at.ua/2019_1/42.pdf> (2021, серпень,18)

${ }^{2}$ Іжа, М., Голинська, О., Матвєєнко, І. (2021). Підготовка кадрів місцевого самоврядування в Україні:

нові виклики та перспективи. Одеський Регіональний інститут державного управління, 1(82)

<http://www.oridu.odessa.ua/9/new_options/pdf/021/Zbirnuk-1-82-2021.pdf> (2021, серпень, 21)

${ }^{3}$ Палагнюк, Ю. В. (2019). Сутність та особливості використання методів мотивування персоналу в органах місцевого самоврядування. Теорія та практика державного управління і місцевого самоврядування, 1 $<$ http://nbuv.gov.ua/UJRN/Ttpdu_2019_1_42> (2021, серпень, 24)
} 
належить проведення супервізії ${ }^{1}$, спрямованої на подолання професійних труднощів, аналіз та усунення недоліків, вдосконалення організації роботи, стимулювання мотивації до роботи, дотримання етичних норм та стандартів надання соціальних послуг, запобігання виникненню професійного вигорання, забезпечення емоційної підтримки.

Висновки 3 даного дослідження і перспективи подальших розвідок у даному напрямку.

Здійснивши теоретичний аналіз мотивації праці посадових осіб місцевого самоврядування, працівників комунальних установ було виявлено чинники (психологічний, соціальний, кар'єрний, освітній, матеріальний), які здійснюють вплив на мотивацію праці працівників надавачів соціальних послуг, як таких, які працюють з особами/сім'ями, які опинилися в складних життєвих обставинах. 3 метою формування соціальної довіри в громаді, органам місцевого самоврядування, керівникам комунальних установ органів місцевого самоврядування слід враховувати особливості роботи працівників з отримувачами соціальних послуг, які відносяться до осіб, сімей, які опинилися в СЖО. Доцільним у даному випадку є здійснювати заходи запобігання професійному вигоранню; психологічному розвантаженню; проведення супервізії; сприяння регулярному професійному розвитку; соціальної активності; заохочувати матеріальними складовими; сприяти кар'єрному зростанню, формувати сприятливу атмосферу в колективі.

Для забезпечення професійного надання соціальних послуг на рівні територіальної громади, 3 метою формування мотивації праці необхідним є забезпечення працівників надавачів соціальних послуг необхідними умовами здійснення трудової діяльності. По-перше, матеріально-технічним забезпечення, зокрема сучасним технічним обладнанням, вільним доступом до мережі інтернет. По-друге, забезпечення інструментами для проведення консультування, наприклад метафоричними асоціативними картами для здійснення психотерапії, або ж діагностичним інструментарієм для виявлення профорієнтації, також матеріалами раннього розвитку для роботи з дітьми тощо. По-третє, необхідним є виділення транспорту для швидкого реагування та запобігання або ж подолання СЖО. Такі прості речі впливають на загальний професійний рівень та якість надання соціальних послуг, тим самим забезпечують формування мотивації працівників, які здійснюють соціальну роботу, зокрема надають соціальні послуги в громадах.

У подальшому плануємо проаналізувати зарубіжний досвід мотивації працівників надавачів соціальних послуг на місцевому рівні.

\section{References:}

1. Bezpalko, O. V., Zvereva, I. D., Kiyanitsa, Z. P., Kuzminsky, V. O. (2007). Intehrovani sotsialni sluzhby: teoriya, praktyka, innovatsiyi [Integrated social services: theory, practice, innovation]. Kyiv: Phoenix. (2021, August, 08). [in Ukrainian].

2. Bondar, V. D. (2012). Motyvatsiya diyalnosti orhaniv mistsevoho samovryaduvannya: ponyattya ta osnovni teoretychni polozhennya [Motivation of local government: concepts and basic theoretical provisions].

Derzhavne upravlinnya: udoskonalennya ta rozvytok [Public administration: improvement and development], 5. <http://www.dy.nayka.com.ua/?op=1\&z=435http://el-zbirn-du.at.ua/2019_1/42.pdf> (2021, August, 18 ) [in Ukrainian].

3. Detsentralizatsiya [Decentralization] (2019). Posibnyk iz vyznachennya potreb naselennya obyednanoyi terytorialnoyi hromady u sotsialnykh posluhakh. Praktychni rekomendatsiyi [A guide to identifying the social services needs of the population of the united territorial community. Practical recommendations] Kyiv <https://decentralization.gov.ua/uploads/library/file/496/> (2021, August, 20). [in Ukrainian].

4. Zakon Ukrayiny Pro sotsialni posluhy, 2019 (Verkhovna Rada Ukrayiny) [Law of Ukraine on Social Services, 2019 (Verkhovna Rada of Ukraine)]. Ofitsiynyy sayt Verkhovnoyi Rady Ukrayiny [Official site of the Verkhovna Rada of Ukraine] <https://zakon.rada.gov.ua/laws/show/2671-19\#Text> (2021, August, 08). [in Ukrainian].

5. Izha, M., Holynska, O., Matvyeyenko, I. (2021). Pidhotovka kadriv mistsevoho samovryaduvannya v Ukrayini: novi vyklyky ta perspektyvy [Training of local self-government in Ukraine: new challenges and prospects]. Odeskyy Rehionalnyy instytut derzhavnoho upravlinnya [Odessa Regional Institute of Public Administration], 1 (82) <http://www.oridu.odessa.ua/9/new_options/pdf/021/Zbirnuk-1-82-2021.pdf> (2021, August, 21). [in Ukrainian].

6. Kiyanitsa, Z. P., Petrochko, Zh. V. (2017). Suchasni oriyentyry ta klyuchovi tekhnolohiyi. Sotsialna robota z vrazlyvymy simyamy ta ditmy [Modern landmarks and key technologies. Social work with vulnerable families and children]. Kyiv: Renewal of the Company, 1. (2021, August, 08). [in Ukrainian].

\footnotetext{
1 Закон Украйни Про соиіальні послуги, 2019 (Верховна Рада України). Офіційний сайт Верховної Ради України <https://zakon.rada.gov.ua/laws/show/2671-19\#Tеxt> (2021, серпень, 08).
} 
7. Kobernyk, I., Krasnova, K. (2019). Efektyvni komunikatsiyi dlya osvitnikh upravlintsiv [Effective communications for educational managers]. Nova Ukrayinska shkola [New Ukrainian school] <https://nus.org.ua/wp-content/ uploads/2019/12/efektyvni-komunikacii-posibnyk-final-preview-20-12.pdf> (2021, August, 16). [in Ukrainian].

8. Palahnyuk, Yu. V. (2019). Sutnist ta osoblyvosti vykorystannya metodiv motyvuvannya personalu v orhanakh mistsevoho samovryaduvannya [The essence and features of the use of methods of motivating staff in local governments]. Teoriya ta praktyka derzhavnoho upravlinnya $i$ mistsevoho samovryaduvannya [Theory and practice of public administration and local self-government], 1 <http://nbuv.gov.ua/UJRN/Ttpdu_2019_1_42> (2021, August, 24). [in Ukrainian].

9. Semigina, T. (2020). Suchasna sotsialna robota [Modern social work]. Kyiv: Academy of Labor, Social Relations and Tourism <https://www.researchgate.net/profile/Tetyana - Semigina/publication/342003632_Sucasna_socialna_robota/ links/5eddf6ae299bf1d20bd86768/Sucasna-socialna-robota.pdf> (2021, August, 08). [in Ukrainian]. 